Acta Universitatis Sapientiae, Philologica, 8, 3 (2016) 5-15

DOI: 10.1515/ausp-2016-0027

\title{
Bilingualism and Diglossia as Sociocultural Phenomena in Romanian-Hungarian Translations in Transylvania
}

\author{
András ZOPUS \\ Institution of Linguistics and Literature \\ University of Nyíregyháza \\ drsza@yahoo.com
}

\begin{abstract}
My study aims to scrutinize the extent to which bilingualism and diglossia influence Transylvanian translators' texts when the target language is Hungarian. While studying the narrower and wider interpretations of these linguistic phenomena, we may find that all the conditions are given that are required for us to say: Transylvanian translators' bilingualism and diglossia may be considered as facts, and socio-lingual effects become tangible in various translations.
\end{abstract}

Keywords: bilingualism, diglossia, translator, translation, Transylvania

While working as both a translator and teacher, I encounter various translations almost day by day, either when doing a translation or checking a specific translation. Exploring the extent to which the translators' bilingualism/ diglossia influences their completed assignments, I aim to describe some aspects of several Romanian-Hungarian translations prepared by a number of translators from Transylvania. The phenomena I scrutinize in my study do not link simply to a single translator and his/her translations; I have a close look at the general characteristics of numerous translations prepared all over in Transylvania. The official language of the state - being in majority and influencing minorities -, the more or less satisfactory knowledge of Romanian culture and traditions make the presence of lingual-cultural influences tangible in various translations. These influences, however, should appear in the translator's theoretical knowledge only, not at all in the complete translation.

Amongst translators, one can frequently find people who translate - mastering two languages or more -, but do not possess the basic sorts of a translator's competence. It may be a cliché, but bilingualism does not automatically mean preparing professional translations. To analyse the lingual-cultural influences 
appearing in the translations in question, we need to differentiate bilingualism and diglossia for these situations are not clearly uniform or equivalent.

Several definitions have been created to define bilingualism. One of the most inclusive and general definitions was provided by Bloomfield (Bloomfield 1933: 56). He considered 'real' bilinguals those mastering both languages at a nativelike level. This approach is called 'double monolingualism', i.e. bilingualism is simply a mechanical aggregate of two languages. On the contrary, in 1961, Diebold set up a minimal definition of bilingualism as the aforementioned knowledge of a native language. In Diebold's definition, bilingualism is 'the ability of contacting the possible models of a second language and using these in the context of the mother tongue'. ${ }^{1}$ Accordingly, those only understanding - more or less - some communication in the second language are also bilingual. In 1977, Haugen's theory suggested that those people are bilingual who have basic second language skills through which they are able to form complete and sensible sentences.

In an ideal case, coexistent lingual systems are characterized by balanced bilingualism, i.e. the individual knows both languages to the same extent. In everyday reality, this condition is rather exceptional amongst the translators. In fact, a translator's levels of competence for both languages are mainly quite different when performing translation processes. On the basis of this premiss: language is the device for communicating and thinking; we may add the following sorts of sociolinguistic competence to the constituents of linguistic competence (Várkuti, 2006):

1. Linguistic competence (the knowledge of vocabulary and grammatical rules);

2. Communicative competence (the knowledge of accepted linguistic behaviour in the current situation);

3. Communicative competence of technical terms.

Therefore, the competence of technical terms founded on complex interactions ought to be a basic skill for all the technical translators. This is defined by Douglas as follows:

'Specific purpose language ability results from the interaction between specific purpose background knowledge and language ability, by means of strategic competence' (Douglas 2000: 40) - in a specific-purpose context. In the given situation of specific-purpose communication, conveying information and decoding meanings are ensured by specific knowledge and relevant content because the translator - relying on his/her own set of competence and abilities uses his/her command of language and specific-purpose background knowledge in such a way that the message through the translator's communication should have sensible linguistic units (performances) both for himself/herself and the 
recipient(s) of the target language. What Douglas called specific-purpose language ability - which reveals in communicative specific-purpose language contexts and requires a predetermined language use required by the technical context by definition - is communicative specific-purpose language competence.

The Baker model is one of the most appropriate ways to depict the mental representation of bilingual competence and the acquisition of linguistic systems (Baker 2002: 145):

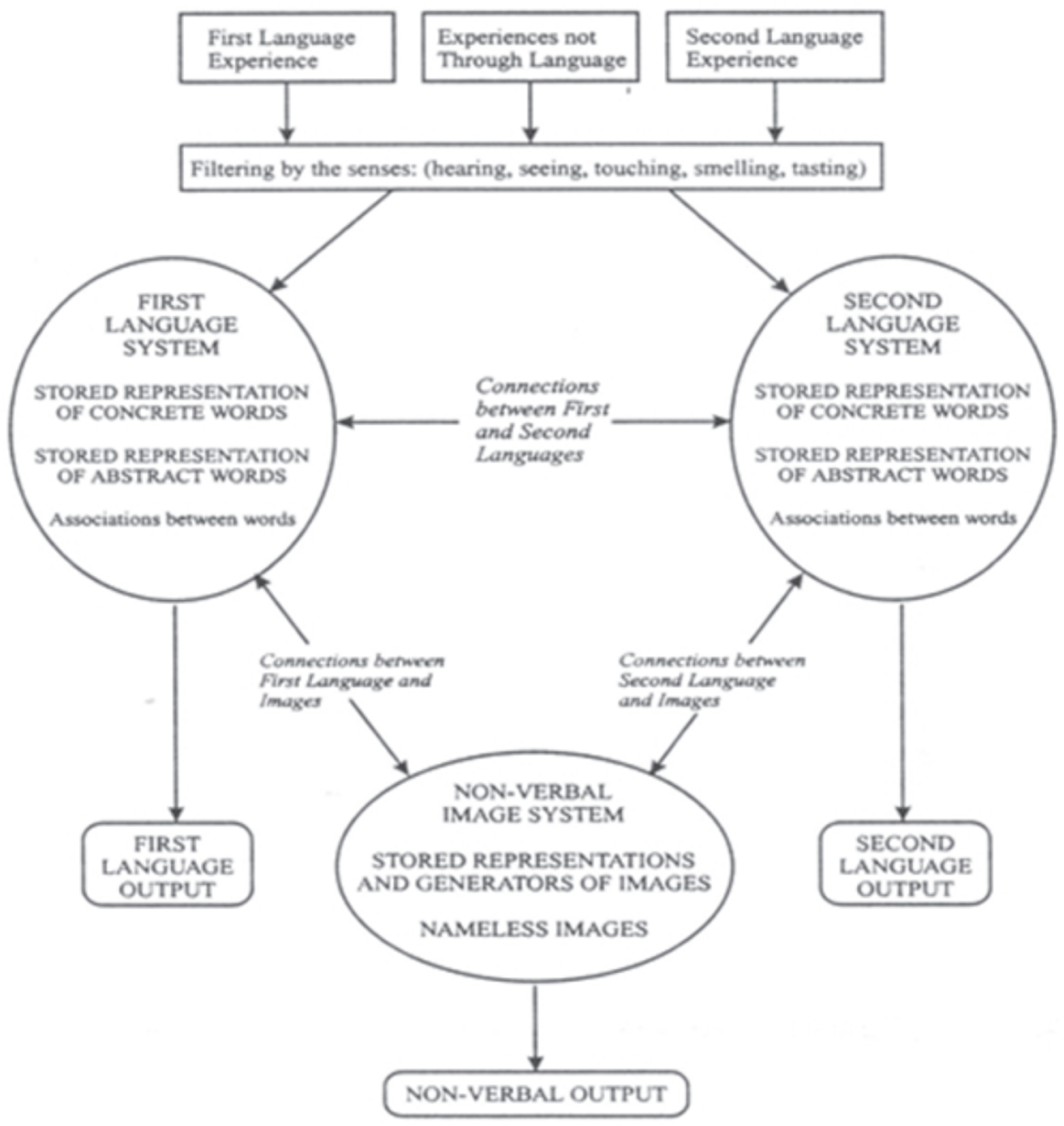

Figure 1. Bilingual dual-coding model

Regarding Transylvanian translators, diglossia possibly comes up in addition to bilingualism. Charles Ferguson was the first linguist to determine the concept 
of diglossia, defined as a linguistic situation in which there are two coexistent versions but having utterly different social functions in a given community (Ferguson 1959: 354). The essence of Ferguson's definition is that the functions of the two variations detach from each other in a relevant way; but then again both dialects are spoken by each member of the community: the 'high' one $(\mathrm{H})$ is the language of religion, politics, scientific presentations, high culture, news service, newspapers, and poetry, while the low (L) one is that of private conversations, show business, and vernacular literature. These two variations coexist, rounding out each other, and neither is used for the other's function. There are several important features of situations of diglossia, but we may emphasize from these the fact that version $\mathrm{L}$ is acquired at home, thus becoming the mother tongue of everyone, while variation $\mathrm{H}$ is not spoken as a mother tongue but learnt at school. As a consequence, variation $L$ is 'perfectly' known by every speaker; they, however, show differences of perfection regarding variation $\mathrm{H}$. It is highly prestigious in diglossic communities; many times, it is considered 'nicer' or 'more logical' by the speakers than variation $\mathrm{L}$. Then again, the latter one is the symbol of internal unity of the community as well. In the speakers' minds, the two variations distinctly detach from each other, and, accordingly, literature has termed them separately. Variation $\mathrm{H}$ has completely standardized, uniform and accepted norms, while variation L does not always have any written form either. If not so, there may be several local forms as well. There may be various differences of various degrees in terms of grammar and vocabulary between variations $\mathrm{H}$ and $\mathrm{L}$.

It is specific to diglossia that the vocabularies of variations $\mathrm{H}$ and $\mathrm{L}$ are mainly the same, but they contain very typical, distinct pairs of words; the grammar of variation $\mathrm{H}$ tends to be more sophisticated, including structures not to be found in variation L. The prerequisite of the genesis of diglossia is that the community of speakers should have a long written legacy. In this way, spoken variations may be rather different from the variations of literacy, which are always more conservative than spoken variations. It is also necessary that only few should possess variation $\mathrm{H}$ for a long time, so knowing it ensures high authority, perpetuating and enhancing segregation in society. Summing up, diglossia applies to a certain community of speakers, but not necessarily to all of its members: maybe the prestigious variation $\mathrm{H}$ is understood and may be used by a thin stratum only.

The relatively inflexible system of the Fergusonian diglossia is expanded by Fishman, who distinguishes bilingualism and diglossia, and uses these concepts in a slightly unconventional way. By bilingualism he means the psychological state of a person who speaks more than one language variations; and by diglossia, the social distribution of language variations used for various communicative purposes (Schleicher 1997: 124). Pursuant to this approach, Fishman has a broad interpretation of diglossia, and also accepts if variations $\mathrm{H}$ and $\mathrm{L}$ are not cognate; 
moreover, if there is a functional division between a standard language and one of its dialects, he terms this situation diglossia as well. It follows that a number of dialects (a number of variation L's) may also belong to the same standard language (variation H). The chart below summarizes Fishman's theory:

Table 1. Fishman's reformulation

\begin{tabular}{lll}
\hline & + Diglossia & - Diglossia \\
\hline + Bilingualism & Everyone in a community & An unstable, transitional \\
& knows both H and L, & situation in which everyone \\
& which are functionally & in a community knows both \\
& differentiated. & H and L but are shifting to H. \\
\hline - Bilingualism & $\begin{array}{l}\text { Speakers of H rule over } \\
\text { speakers of L. }\end{array}$ & $\begin{array}{l}\text { A completely egalitarian } \\
\text { speech community, where } \\
\end{array}$ \\
& there is no language variation. \\
\hline
\end{tabular}

Analysing the previous theories and models, Fasold formulates several criteria, the aggregate of which is sufficient for us to speak about diglossia: Function, Prestige, Literary Heritage, Acquisition, Standardization, Stability, Grammar, Lexicon, and Phonology (Fasold, 1984). On the basis of the above criteria, Fasold makes distinction between three cases of diglossia: overlapping diglossia, double-nested diglossia, and linear polyglossia; and after reviewing literature, he formulates the following definition:

In a broader sense, diglossia means that a community uses a highly-esteemed segment of its linguistic repertoire (this segment is usually acquired not first but later, consciously and through formal education) in situations considered to be more formal, controlled; and a less-esteemed segment (which is the first to be learnt, with minimal conscious effort, if any) that may have links of any degrees from stylistic differences to different languages - to the highly-esteemed segment, in situations regarded more informal and confidential (Fasold 1984: 53).

Diglossia may be best explained by using Harold's concentric model (Harold 2005: 2108): its way of approach makes it clear how variation L - considered to be of lower prestige - is surrounded by both the variations of educated languages and the variation $\mathrm{H}$ of the mother language (2).

While analysing the definitions of bilingualism and diglossia, we may state that Transylvanian translators' situation is clear from the point of view of bilingualism because criteria in broader and narrower senses are met, e.g.: both Hungarian and Romanian are mastered as mother tongues (Bloomfield 1933), translators have one of the four basic communicative skills (speaking, listening comprehension, writing, and reading) in the second language (in this case: Romanian) in addition to the first one (MacNamara 1967), they are able to communicate in at least two languages in a mono- or multilingual community as well, and they are able to 
identify themselves or sympathize with both (or all) groups of languages and cultures partly or completely (Skutnabb-Kangas 1984).

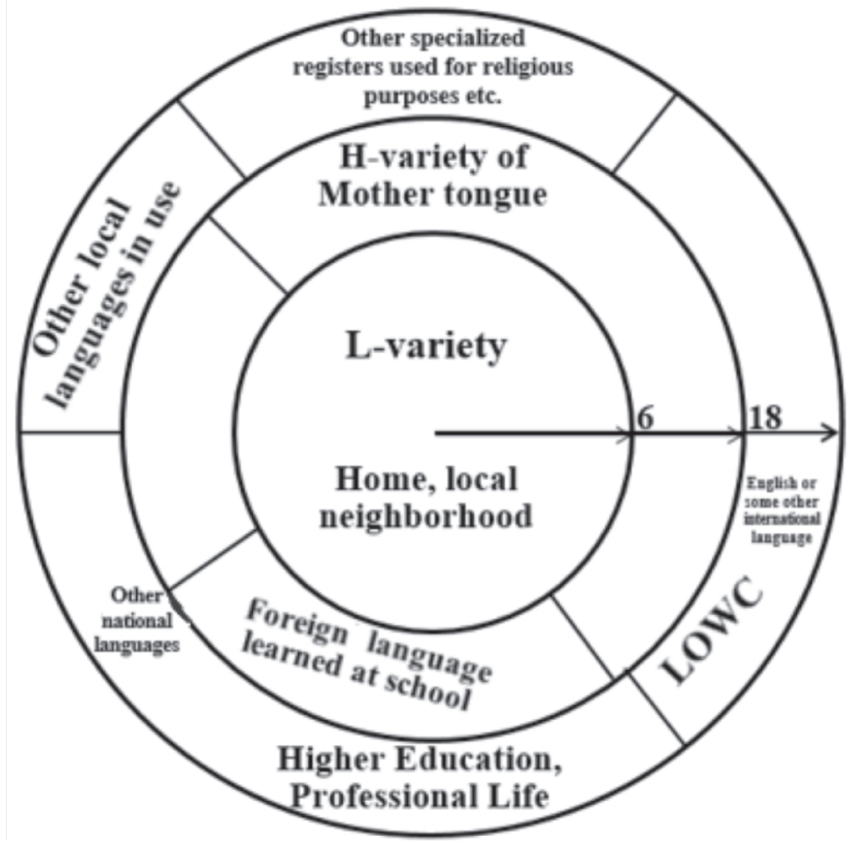

Figure 2. Language repertoires as a function of age, education, and life experience

The situation is not so clear from the point of view of diglossia because Ferguson's criteria (variations L and H) do not seem to be met as neither dialects - including the Székely dialect - nor the dialects spoken in scattered areas may be considered inferior variations of standard Hungarian by the classical definitions and criteria of diglossia either. To justify that there is diglossia in some sense amongst the given Transylvanian translators, we need to talk about a regional standard language which has evolved at the boundaries of dialects. This regional standard language is a variation of the standard language, the first one having evolved through dialectical interactions; moreover, its place is between dialects and the standard language in terms of its relationship to norms. When writing, its users use the literary variation, while their utterances are dominated by standard language norms, but one can observe the traits of surrounding dialects, depending on locality and time to various extents. That regional standard language as a phenomenon of contacts has appeared may be interpreted not only as the expansion of standard language towards regionalism but also as the spot of intrusion of regionality into standard language. According 
to the model of variability, under the influence of standard language, the rules of competence of dialects are added to those rules of the standard language in such a way that some that are typical to dialects remain. In addition, we may say that a new regional substandard is taking shape as a consequence of primarily three tendencies: dialects are pushed back, they are becoming variable and destandardizing, and they are losing their diglossic features (3). 'Obviously, losing diglossic features may take place amongst diglossic speakers only (dialectal + regional standard lingual, dialectal + standard lingual, regional standard lingual + standard lingual), resulting in giving up the dialect or the regional standard language' (Kiss 2013: 88).

Although diglossia applies basically to the relationship between standard language and dialect $^{2}$ (Kiss 1995: 232), in my opinion, the questions arising during the usage of standard language and the regional standard language may also be relevant here. On the basis of the examined translations, we may state that diglossia - in addition to bilingualism - is also typical of most Transylvanian translators. If so, we may also state they know two non-stylistic variations of a given language (in our case: Hungarian), and they use them according to the situations of translation. ${ }^{3}$ In translating, we may observe several instances when translators prefer some variation to others (the preferred one is usually their regional standard language) and, when preparing texts in the Hungarian target language, they use the regional standard language of the given locality, using this to interpret source texts and create the technical terms and concepts for the target texts. When preparing and interpreting target texts to be written in Hungarian, Transylvanian translators very often neglect the technical language of law, economy, etc. ${ }^{4}$ used in Hungary - therefore, these sorts of languages connect to standard Hungarian. Instead, they tend to use the concepts, expressions, and translation routines of the regional standard language known to them, a practice which often results in misunderstandings and incorrect translations, e.g. (4):

The language data analysed should be classified according to the type of contact phenomenon: direct, indirect, and hybrid structures.

(1) direct borrowings (loanwords):

Karióka ('felt-tip pen'): the transcribed form of the Romanian 'cariocă'. Correctly: filctoll ('felt-tip pen').

Doszár ('dossier'): the transcribed form of the Romanian 'dosar'. Correctly: dosszié ('dossier').

2 'Diglossia's "high" variation pair is the current standard language, its "lower" pair, a dialect'.

3 E.g.: not knowing or mistakenly knowing laws or technical terms used in Hungary; the relationship between standard Hungarian, sorts of technical language, and the translator using a regional standard language; the translator's competence in terms of mother tongue, etc.

To term this phenomenon, western literature often uses 'bidialectalism'. 
Perfúzió ('infusion'): the transcribed form of the Romanian 'perfuzie'. Correctly: infúzió ('infusion').

Pix ('ball-pen'): the transcribed form of the Romanian 'pix'. Correctly: golyóstoll ('ball-pen').

Maszlina ('olive'): the transcribed form of the Romanian 'măslină'. Correctly: olívabogyó or olajbogyó ('olive').

Buletin ('identity card'): the transcribed form of the Romanian 'buletin'. Correctly: személyazonossági igazolvány ('identity card).

Ficujka ('a slip of paper'): the transcribed form of the Romanian 'fițuică'. Correctly: cetli ('a slip of paper').

Vinete ('aubergine'): the transcribed form of the Romanian 'vânătă'. Correctly: padlizsán ('aubergine').

Punga ('a big or small plastic bag'): the transcribed form of the Romanian 'pungă'. Correctly: múanyag szatyor, zacskó ('a big or small plastic bag').

Jaurt ('yogurt'): the transcribed form of the Romanian 'iaurt'. Correctly: joghurt ('yogurt').

Szponzorizál ('to sponsor'): the transcribed form of the Romanian 'sponsorizează'. Correctly: szponzorál ('to sponsor').

(2) indirect borrowings (loanshifts):

Fizikai személy ('physical person'): the verbatim translation of the Romanian 'persoană fizică'. Correctly: természetes személy ('natural person').

Egészségügyi rendôrség ('sanitary police'): the verbatim translation of the Romanian 'poliția sanitară'. Correctly: tisztiorvosi szolgálat ('medical officer's service'), sometimes egészségügyi felügyelôség ('sanitary inspectorate').

Közszállítás ('common transport'): the verbatim translation of the Romanian 'transport în comun'. Correctly: tömegközlekedés ('public transport').

Régiség ('oldness'): the verbatim translation of the Romanian 'vechime (în muncă)'. Correctly: szolgálati idô, munkaviszony, szakmai gyakorlat ('period of service', 'employment', 'field practice').

(3) hybrid structures:

Budzsetáris intézmény ('budgetary institution'): appears as the verbatim translation of the Romanian 'instituție bugetară' in Hungarian official language and translations in Romania. Correctly: költségvetési intézmény ('budgetary institution'), i.e.: an institution financed through the national budget.

Sofóriskola ('to sponsor'): the verbatim translation of the Romanian 'şcoală de şoferi'. Correctly: autósiskola ('driving school').

Similarly to the northern and southern Hungarian regional standard languages, the Transylvanian one is also distinguished by the marks of being isolated from the Hungarian standard language, and of developing separately. Translators' 
attitudes towards regional variations and views of regional standard language are duly reflected in translations. Since regional standard language is the result of the equalization between dialects and the variation of standard language, i.e. it is a special language usage having functions linked to standard language but also showing features of regionalism, due to the regional awareness of identity, it is the units of regional standard language that occur in translations as well. We may observe the higher prestige of regional standard language in the case of secondary school students in Szeklerland, too. Their value judgement of language is permeated by the Transylvanistic attitude and views of life; they have a positive attitude towards their mother tongue/mother dialect. The (standard) variation in Hungary seems to be of a lower prestige - a way of attitude, which may originate from being a minority (Bodó-Lukács 2012: 5). We may as well regard the occurrence of units of regional language in translations as a symbol of the cohesion of community - although that occurrence contradicts both standard language and technical language.

Bilingual translators have a dual linguistic competence. This, however, is not always equally precise, i.e. it is more complex and comprehensive in the case of the first language than in the other one(s). Bilingual translators' technical knowledge and qualifications are often incomplete in terms of Hungarian standard and technical languages. A profound knowledge is, however, essential for them to translate source language texts (here: Romanian ones) into the target language (Hungarian) in a proper, professional, and accurate manner. The vast majority of Transylvanian translators with Hungarian mother tongue have linguistic competences regarding both languages, but it will not follow that they automatically choose the appropriate translation structure or technical term on the basis of linguistic competences. Namely, linguistic competence is simply necessary but not sufficient to do professional and accurate translations. We may state that bilingual translators may be at outstanding levels of writing and reading competences with regard to both languages, but this is still not sufficient for the accurate translation of texts or documents as being of various kinds. A technical translator needs to attain a special linguistic training to do accurate translations meeting professional requirements. If the translation is done by a bilingual translator lacking practice and professional skills, he or she will not be able to render the meaning and nuances of the original text, and therefore translations done by that translator may include misunderstandings and mistakes.

In sum, we may state that bilingualism and diglossia imply and ensure unlimited advantages for translators in addition to the threats inherent in translations; in translations, these are units being fully intelligible to the users of regional standard language but incorrect from the viewpoint of technical translations, and sometimes even unintelligible to customers using standard Hungarian. 


\section{References}

Baker, C. 2002. Foundations of bilingual education and bilingualism. In: Bilingual education and bilingualism. Series: 27. Clevedon-Buffalo-Toronto-Sydney.

Bloomfield, L. 1933. Language. Holt, Rinehart \& Winston, New York.

Bodó-Lukács, Cs. 2012. Székelyföldi középiskolások anyanyelvi tudata és anyanyelvhasználata szociolingvisztikai megközelítésben. Doktori disszertáció ('The awareness of native language amongst secondary school students in Szeklerland: a socio-lingual point of view.' PhD dissertation): http:// doktori. btk.elte.hu/lingv/bodolukacscsilla/tezis.pdf.

Diebold, R. 1961. Incipient bilingualism. In: Language 37: 97-112.

Douglas, D. 2000. Assessing languages for specific purposes. Cambridge University Press, Cambridge.

Fasold, R. 1984. The sociolinguistics of society. Wiley-Blackwell, Oxford.

Ferguson, Ch. 1959. Diglossia. In: Bratt Paulston, Ch. \& Tucker, G. R. (eds), Sociolinguistics. The essential readings. Malden (MA). Blackwell Publishing, Oxford.

Haugen, E. 1977. Norm and deviation in bilingual community. In: Hornby, P. (ed.), Bilingualism: psychological, social, and educational implications. Academic Press, New York.

Kiss, J. 1995. Társadalom és nyelvhasználat. ('Society and Use of Language'). Nemzeti Tankönyvkiadó, Budapest.

2013. A regionális nyelvhasználat és a nyelvi kontaktusok. Problémavázlat. ('The use of regional language and language contacts.' A draft). Nyelvelmélet és Kontaktológia 2. ('Theory of language and contactology 2.'). 80-94.

Macnamara, J. 1967. The bilingual's linguistic performance. Journal of Social Issues 23: 58-77.

Schiffman, F. H. 2005. Bilingualism in South Asia: friend or foe? In: James Cohen, Kara T. McAlister, Kellie Rolstad, Jeff MacSwan (eds), Proceedings of the $4^{\text {th }}$ International Symposium on Bilingualism. 2104-2114. Somerville, MA: Cascadilla Press.

Schleicher, N. 1997. A diglosszia elméletei és kritikája. ('Theories and critique of diglossia'). Jel-Kép. 123-130.

Skutnabb-Kangas, T. 1984. Bilingualism or not: the education of minorities. Multilingual Matters, Avon, Cleveland.

Várkuti, A. 2006. Bilingvis kompetencia, kognitív elméletek és a kétnyelvűség hatásai az oktatásban. ('Bilingual competence, cognitive theories, and the effects of bilingualism in education'): http://www.kettannyelvu.com/public/ varkuti \% 20anna \% 20(2006)\% 20bilingvis \% 20kompetencia, \% 20kognitiv \% 20 elmeletek\%20es\%20a\%20ketnyelvuseg.ppt (20.3.2016). 


\section{Internet sources}

Havril, Á. A szaknyelvtudás konstruktumának modellezése. ('Modelling the construct of technical language command'): http://www.kodolanyi.hu/ manye/2011_szombathely/kotet/45_havril.pdf. (20.03.2016.).

Schiffman, F. H. Examples of complex real situations. http://ccat.sas.upenn. edu/ haroldfs/messeas/regrep/node4.html (20.03.2016).

Kiss, J. A regionális nyelvhasználat és a nyelvi kontaktusok. ('The use of regional language and language contacts'): https://btk.ppke.hu/uploads/articles/16444/ file/Kiss\%20Jen\%C5\%91.doc (20.03.2016).

Komoróczi, Gy. Erdélyi Magyar Nyelvmúvelő Zsebkönyv. ('Transylvanian handbook of correct usage'): http://www.diva.eoldal.hu/cikkek/erdelyi-magyar-nyelvmuvelo-zsebkonyv.html. 